\title{
Serotonin Modulates Pallidal Neuronal Activity in the Awake Monkey
}

\author{
Hitoshi Kita, ${ }^{1}$ Satomi Chiken, ${ }^{1,2}$ Yoshihisa Tachibana, ${ }^{2}$ and Atsushi Nambu ${ }^{2}$ \\ ${ }^{1}$ Department of Anatomy and Neurobiology, College of Medicine, University of Tennessee Memphis, Memphis, Tennessee 38163, and 2Division of System \\ Neurophysiology, National Institute for Physiological Sciences, and Department of Physiological Science, The Graduate University for Advanced Studies, \\ Okazaki 444-8585, Japan
}

Serotonin (5-HT)-containing neurons in the dorsal raphe project to the external and internal segments of the pallidum, which express several 5-HT receptors. Although the involvement of 5-HT in basal ganglia movement control has been suggested, little is known about the physiological action of 5-HT in the pallidum. Previous anatomical studies and in vitro physiological studies in other brain areas have

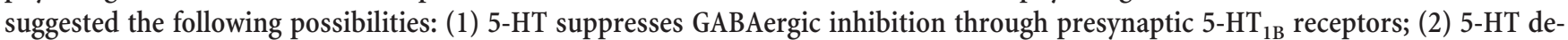
creases the firing of pallidal neurons through postsynaptic 5- $\mathrm{HT}_{1 \mathrm{~A}}$ receptors; and (3) 5-HT postsynaptically excites pallidal neurons through activation of $5-\mathrm{HT}_{2 \mathrm{C}}, 5-\mathrm{HT}_{4}$, or 5- $\mathrm{HT}_{7}$ receptors. To test these possibilities, we examined the effects of locally applied agonists and antagonists of 5-HT on spontaneous neuronal firing and on excitatory and inhibitory responses of pallidal neurons to electrical stimulation of the motor cortex in awake monkeys. Although in vivo experiments could not conclusively determine the receptor types or the active sites involved in the observed effects, the results suggested the following possibilities: (1) 5-HT strongly suppresses GABAergic inhibition probably through $5-\mathrm{HT}_{1 \mathrm{~B}}$ receptors; (2) in the external pallidal segment, the suppression may involve additional receptors or mechanisms; and (3) 5-HT suppresses glutamatergic excitation probably through 5- $\mathrm{HT}_{1 \mathrm{~A}}$ (and not 5-HT ${ }_{1 \mathrm{~B}}$ ) receptors. The present study did not isolate or identify the existence of strong, direct postsynaptic inhibitory or excitatory effects of 5-HT. Thus, present results imply that 5-HT modulates synaptic inputs of both pallidal segments and exerts a significant role in movement control.

Key words: globus pallidus; serotonin; unit recording; 5- $\mathrm{HT}_{1 \mathrm{~A}}$ receptor; 5- $\mathrm{HT}_{1 \mathrm{~B}}$ receptor; awake monkey

\section{Introduction}

The external (GPe) and internal (GPi) segments of the pallidum play key roles in the physiology and pathophysiology of the basal ganglia (Nambu, 2004; Kita et al., 2005b; Wichmann and Soares, 2006). The level and pattern of pallidal firing activity change with the development of basal ganglia diseases (Filion and Tremblay, 1991; Nini et al., 1995; Boraud et al., 2001; Wichmann and Soares, 2006). Thus, we have been exploring the mechanisms controlling pallidal activity to better understand the role of the pallidum in normal and pathological conditions.

The literature suggests that serotonin (5-HT) actions in the pallidum exert significant roles in movement control (Castro et al., 1998; Doder et al., 2003; Jackson et al., 2004). Anatomical studies have shown that both segments of the pallidum receive abundant 5-HT innervations from the dorsal raphe (Pasik et al., 1984; Vertes, 1991; Charara and Parent, 1994). Immunohistochemical (Sari et al., 1999; Neumaier et al., 2001), receptor bind-

Received Sept. 17, 2006; revised Nov. 20, 2006; accepted Nov. 21, 2006.

This work was supported by National Institutes of Health Grants NS-42762 and NS-47085 and by the Japan Society for the Promotion of Science. We thank R. Kita for editing this manuscript and A. Kita for helping with the statistical analysis.

Correspondence should be addressed to Hitoshi Kita, Department of Anatomy and Neurobiology, College of Medicine, The University of Tennessee Memphis, 855 Monroe Avenue, Memphis, TN 38163. E-mail: hkita@utmem.edu.

DOI:10.1523/JNEUROSCI.4058-06.2007

Copyright $\odot 2007$ Society for Neuroscience $\quad$ 0270-6474/07/270075-09\$15.00/0 ing (Appel et al., 1990; Waeber and Moskowitz, 1995; Vilaro et al., 1996), and in situ hybridization (Wright et al., 1995; Ullmer et al., 1996) studies localized several 5-HT receptor subtypes in the pallidum. The 5-HT innervations decrease in advanced stages of Parkinson's disease (Halliday et al., 1990; Jellinger, 1990; Chinaglia et al., 1993; Kish, 2003). Furthermore, treatments with 5-HT and $5-\mathrm{HT}_{4}$ receptor agonists and $5-\mathrm{HT}_{2}$ receptor antagonists are beneficial for Parkinson's disease patients (Henderson et al., 1992; Nicholson and Brotchie, 2002; Johnston and Brotchie, 2004; Asai et al., 2005).

However, physiological studies of 5-HT on the pallidum are very scarce and inconsistent. Perkins and Stone (1983) found that typical high-frequency firing GPe neurons in anesthetized rats were not responsive to iontophoretically applied 5-HT and 5-HT inhibited a small number of low-frequency firing GPe neurons. In contrast, Querejeta et al. (2005) found that local application of 5 -HT or a $5-\mathrm{HT}_{1 \mathrm{~B}}$ receptor agonist excites most of the GPe neurons in anesthetized rats.

The aim of this study was to explore 5 -HT actions by testing the following possibilities through unit recording studies in awake monkeys. (1) 5-HT suppresses GABAergic inhibitions through presynaptic $5-\mathrm{HT}_{1 \mathrm{~B}}$ receptors, which are densely expressed in axons and axon terminals in the pallidum (Bonaventure et al., 1998; Castro et al., 1998; Riad et al., 2000; Sari, 2004; Mostany et al., 2005). Activation of $5-\mathrm{HT}_{1 \mathrm{~B}}$ receptors inhibited ${ }^{3} \mathrm{H}-\mathrm{GABA}$ release from rat GPe slices (Chadha et al., 2000). (2) 
5-HT decreases the firing of pallidal neurons through postsynaptic $5-\mathrm{HT}_{1 \mathrm{~A}}$ receptors. $5-\mathrm{HT}_{1 \mathrm{~A}}$ receptors mediate postsynaptic inhibition in other brain areas (Stevens et al., 1992; Stanford et al., 2005). (3) 5-HT postsynaptically excites pallidal neurons through activation of $5-\mathrm{HT}_{2 \mathrm{C}}, 5-\mathrm{HT}_{4}$, or $5-\mathrm{HT}_{7}$ receptors. Activation of $5-\mathrm{HT}_{2 \mathrm{C}}$ receptors postsynaptically excites substantia nigra pars reticulata ( $\mathrm{SNr}$ ) neurons (Rick et al., 1995), and activation of $5-\mathrm{HT}_{4}$ or $5-\mathrm{HT}_{7}$ receptors excites noncholinergic ventral pallidal neurons (Bengtson et al., 2004). To test these possibilities, we examined the effects of locally applied 5-HT agonists and antagonists on spontaneous firing and on excitatory and inhibitory responses to electrical stimulation of the motor cortex.

\section{Materials and Methods}

Preparation of animals. This study was performed in compliance with the National Institutes of Health Guide for the Care and Use of Laboratory Animals and the National Institute of Physiological Sciences Guide for the Use and Care of Laboratory Animals in Research. The monkey preparation methods used in the present study were very similar to those reported previously (Nambu et al., 2000; Kita et al., 2004, 2005a). Each of three Japanese macaques (Macaca fuscata) was trained to sit quietly in a monkey chair. Before surgery, each monkey was anesthetized with sodium pentobarbital $(25 \mathrm{mg} / \mathrm{kg}$, i.v. ) and ketamine hydrochloride $(10 \mathrm{mg} / \mathrm{kg}$, i.m.) and was placed in a homemade acrylic stereotaxic frame. Then, magnetic resonance images of the head were taken. The monkeys received surgery to install headgear for holding their heads painlessly to a metal stereotaxic frame attached to the chair. Still under the anesthesia, the skull of the monkey was widely exposed. Small stainless steel screws were attached to the skull as anchors, and the exposed skull and screws were covered with acrylic resin. Two stainless steel pipes were mounted in parallel over the frontal and occipital areas of the skull. The monkey was then removed from the chair, allowed to recover in the animal housing facility, and was cared for.

A few days after the initial surgery, a second surgery was performed to implant stimulus electrodes in the hand region of the primary motor cortex (M1) and the supplementary motor cortex (SMA). For the second surgery, the monkey was anesthetized with ketamine hydrochloride (10 $\mathrm{mg} / \mathrm{kg}$, i.m.) and xylazine hydrochloride (1-2 mg/kg, i.m.) and was seated in a monkey chair with its head fixed to a stereotaxic frame. To access the M1 and SMA, a hole was drilled in the skull. After the monkey recovered from the anesthesia, and while it was still in the chair, a glasscoated Elgiloy (Elgin, IL) alloy microelectrode $(0.5-1.5 \mathrm{M} \Omega$ at $1 \mathrm{kHz}$ ) was inserted perpendicularly to the cortical surface. Extracellular unit activity was recorded in 1-1.5 mm intervals of depth across the M1 and SMA, and the neuronal responses to somatosensory stimuli (skin touch and passive joint movement) were examined. After extracellular unit recording, intracortical microstimulation using a train of 12 cathodal pulses $(200 \mu \mathrm{s}$ duration at $333 \mathrm{~Hz}$ ) with currents of $<50 \mu \mathrm{A}$ was delivered, and the movements evoked in the various body parts were observed.

According to the electrophysiological mapping, bipolar stimulating electrodes (made of $200-\mu \mathrm{m}$-diameter enamel-coated stainless steel wire; intertip distance of $2 \mathrm{~mm}$ ) were implanted into the hand regions of M1 and SMA. M1 and SMA stimulation was used to locate the hand areas of the putamen and the pallidum (for details, see Nambu et al., 2000). The monkey was then reanesthetized, and another hole $(10-15 \mathrm{~mm}$ diameter) was drilled in the skull to access the pallidum. A rectangularshaped plastic chamber $(30 \times 55 \mathrm{~mm}$; rostrocaudal and mediolateral dimensions) covering both holes was fixed onto the skull with acrylic resin at an $\sim 20^{\circ}$ tilt from the horizontal plane.

Electrode assembly for unit recording and local injection of drugs. The method for unit recordings was very similar to that of previous studies (Nambu et al., 2000; Kita et al., 2004). During the recording session, the awake monkey was seated in a monkey chair with its head restrained as described above. Single-unit recordings in combination with local applications of antagonists and agonists of 5-HT were performed with an electrode assembly consisting of a homemade epoxylite-insulated tungsten electrode with an impedance of $0.7-1.2 \mathrm{M} \Omega$ (measured with $1 \mathrm{kHz}$ AC) for unit recordings and two silica tubes (outer diameter, $146 \mu \mathrm{m}$; inner diameter, $31 \mu \mathrm{m}$; part number 2000012; Polymicro Technologies, Phoenix, AZ) for drug delivery [see Kita et al. (2004) for more detail about the electrode assembly].

The electrode assembly was inserted obliquely $\left(45^{\circ}\right.$ from vertical) into the pallidum with reference to the recording regions used in previous studies [see hand region of pallidum (Yoshida et al., 1993; Nambu et al., 2000)] and from the responses to M1 and SMA stimulation. Throughout the course of the experiment, $x$-ray images of the frontal and sagittal planes were frequently taken to locate the electrodes. Recordings were made from pallidal neurons that responded to M1 or SMA stimulation but were not made from nonresponding neurons. Each of the drugs used in this study [5-HT; the selective $5-\mathrm{HT}_{1 \mathrm{~A}}$ receptor antagonist $(\mathrm{N}$-[2-[4(2-methoxyphenyl)-1-piperazinyl] ethyl]-N-2-pyridinylcyclohexanecarboxamide (Way100635); the high-affinity agonist for $5-\mathrm{HT}_{1 \mathrm{~A}}$, $5-\mathrm{HT}_{1 \mathrm{~B}}, 5-\mathrm{HT}_{1 \mathrm{D}}, 5-\mathrm{HT}_{5}$, and $5-\mathrm{HT}_{7}$ receptors, 5-carboxamidotryptamine (5-CT); the potent $5-\mathrm{HT}_{2}$ agonist 1 - (2,5-dimethoxy-4iodophenyl)-2-aminopropane (DOI); the 5 - $\mathrm{HT}_{1 \mathrm{~B}}$ receptor agonist 7-trifluoromethyl-4-(4-methyl-1-piperazinyl)pyrrolo-[1,2-a]quinoxaline maleate salt (CGS12066A)] was dissolved in saline (1 mM for all drugs used), and a volume of $0.05-0.2 \mu \mathrm{l}$ was injected into the recording site at a rate of $0.03 \mu \mathrm{l} / \mathrm{min}$ (i.e., the total injection time was $1.7-7 \mathrm{~min}$ ) by advancing the plungers of Hamilton syringes that were connected to the silica tubes with computer-controlled stepping motor-driven actuators.

Our previous study, using the same injection method, indicated that the drug effect became maximized 5-10 min after the injection, and the radius of the affected area was $<1 \mathrm{~mm}$ with a $0.2 \mu \mathrm{l}$ injection (Kita et al., 2004, 2005a). Therefore, once an injection was made, the next injection site was separated by at least $1 \mathrm{~mm}$ from the previous injection site. We confirmed in this and previous experiments that control injections of saline did not alter the firing rate, firing pattern, or cortical stimulationinduced responses.

The method for blockade of the subthalamic nucleus (STN) with the $\mathrm{GABA}_{\mathrm{A}}$ receptor agonist muscimol was also the same as that described previously (Nambu et al., 2000; Kita et al., 2004, 2006). In short, the area of STN responding to M1 stimulation was mapped by unit recording with an Elgiloy electrode. A tungsten electrode attached to the 30 gauge needle of a $10 \mu \mathrm{l}$ Hamilton microsyringe was then used to penetrate vertically into the mapped location of the STN with unit recordings and $\mathrm{x}$-ray images as guides. Muscimol $(0.5 \mu \mathrm{g} / \mu \mathrm{l}$ saline, $0.5-1.0 \mu \mathrm{l}$ ) was injected only once per day. The muscimol effect was verified by the disappearance of the early excitation to cortical stimulation in the pallidum (Nambu et al., 2000; Kita et al., 2004). When the monkey developed strong dyskinetic movements, unit recordings were terminated and pentobarbital $(10 \mathrm{mg} / \mathrm{kg}$, i.m.) was injected. The number of neurons recorded after the STN blockade was small because of these limitations.

Unit recording, cortical stimulation, and data analysis. The electrophysiological methods were very similar to our previous studies (Nambu et al., 2000; Kita et al., 2004). In short, the unit recordings were amplified, passed through a $0.7-2 \mathrm{kHz}$ bandpass filter, and then passed through a homemade time-amplitude window discriminator that has a threshold selection and a window-setting mechanism [a modified version of a similar unit described by Mano and Yamamoto (1978)].

The responses of pallidal neurons to cortical stimulation $(300 \mu \mathrm{s}$ duration single pulse, strength of $100-800 \mu \mathrm{A}$, and interval of $1.4-2$ s) were assessed by constructing poststimulus time histograms (PSTHs) for 50 stimulation trials. The ordinates of all of the PSTHs were converted to the firing rate. PSTHs with a $1 \mathrm{~ms}$ bin width were constructed on-line for initial evaluations. Previous studies have shown that cortical stimulation evokes a sequence of responses in pallidal neurons consisting of an early excitation followed by inhibition and then a late excitation. The early excitation is caused by the activation of the cortico-subthalamo-pallidal pathway, and the inhibition is attributable to the cortico-putamen-pallidal inhibition that overlaps with pallido-pallidal inhibition (Kita et al., 2004, 2005b). The late excitation consisted of multiple responses including the subthalamic excitatory inputs and disinhibition of pallido-pallial inputs (Kita et al., 2005a,b). To assess effects of locally applied 5-HT agonists and antagonists on glutamatergic and GABAergic responses, the 
changes of the early excitatory and inhibitory responses were analyzed, but the late excitation, which consisted of multiple components, was not analyzed.

To assess the strength of the responses, PSTHs with $2 \mathrm{~ms}$ bin widths were generated off-line. The firing during the $100 \mathrm{~ms}$ preceding the stimulation was considered to be the baseline discharge. The changes in the firing activity in response to cortical stimulation were judged to be significant if the firing rate during at least two consecutive bins of the PSTHs exceeded the $95 \%$ confidence interval of the baseline discharge (one-tailed $t$ test for each bin). The magnitudes of early excitation and inhibition were obtained in the following manner. The initiation points of the excitation and the inhibition were defined by having two consecutive bins exceeding the significance level. The end point of early excitation was determined when two consecutive bins fell below the significance level. The end point of the excitation in control conditions was also used for all excitation obtained after drug applications (see Fig. 1). The end point of the inhibitory response was determined by having two consecutive bins below the significance level for each PSTH. The mean firing rate of the baseline discharge minus that of the response (i.e., the area of the response) was determined to be the magnitude of the response.

Because the drug effects were strongest 5-10 min after injection and decayed very slowly (Kita et al., 2004), the spontaneous firing rate, amplitudes, and duration of the responses to M1 and SMA stimulation obtained immediately before and 5-10 min after completion of drug injection were evaluated by paired $t$ test or ANOVA with the Bonferroni/ Dunn post hoc test, and the data are expressed as mean $\pm \mathrm{SD}$ ( $n=$ number of cells; significance level, $p<0.05)$. The rates and patterns of firing were analyzed by calculating the mean rates and autocorrelograms (bin width, $0.5 \mathrm{~ms}$ ) from $50 \mathrm{~s}$ of digitized recordings. The regularity of the firing was assessed from the presence of multiple peaks and their height in the autocorrelograms. The $50 \mathrm{~s}$ of data were also used to obtain burst indices. We chose the proportion of spikes in bursts (percentage) as the index because this was frequently used in other studies and was not correlated with the background firing rate of neurons (Wichmann and Soares, 2006). Bursts were detected by the "surprise" method of Legendy and Salcman (1985) with the surprise value $\geq 3$ and the number of spikes $\geq 3$ in a burst.

These values were adopted from a recent detailed study on burst activity in monkey pallidum and STN (Wichmann and Soares, 2006).

Histology. The histological procedures were the same as published previously (Yoshida et al., 1993; Nambu et al., 2000). In short, several of the recording sites were marked by passing a cathodal direct current $(20 \mu \mathrm{A}$ for $30 \mathrm{~s})$ through the recording electrode. The brains of the monkeys were fixed by tanscardial perfusion of $10 \%$ paraformaldehyde and were cut serially into $50-\mu \mathrm{m}$-thick frontal sections. The sections were stained with $1 \%$ neutral red. The recording and drug injection sites were reconstructed according to the lesions made by current injections and the traces of the electrode tracks (data not shown).
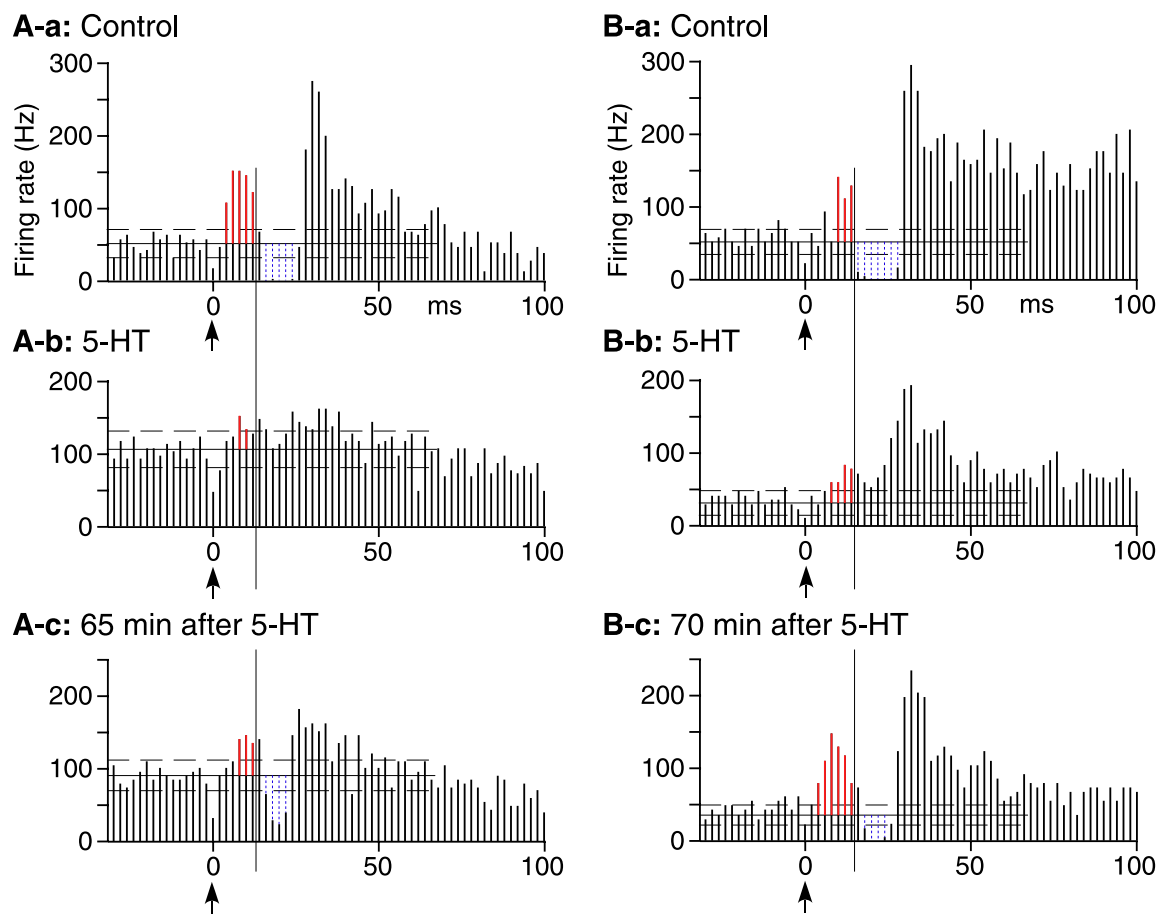

B-c: $70 \mathrm{~min}$ after $5-\mathrm{HT}$

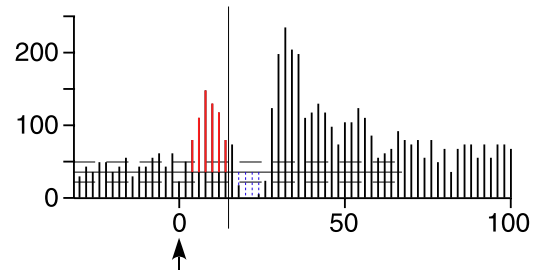

C: Spontaneous firing

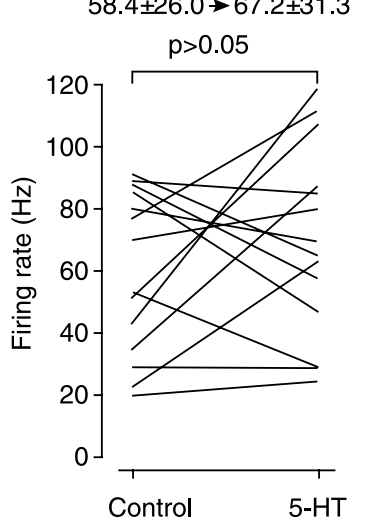

Figure 1. Effects of local application of 5-HT on GPe neurons. $A$, An example of GPe neurons. PSTHs show that $5-H T(1 \mathrm{~mm}, 0.2$ $\mu l)$ increased the firing rate and decreased the early excitatory and inhibitory responses to M1 stimulation. $\boldsymbol{B}$, Another example of GPe neurons. PSTHs show that 5 -HT $(1 \mathrm{~mm}, 0.2 \mu \mathrm{l})$ decreased the firing rate and decreased the early excitatory and inhibitory responses to SMA stimulation. The red and blue bars represent periods of excitation and inhibition, respectively (for details, see $(p<0.05$, determined by one-tailed $t$ tests using the baseline firing rate from $100 \mathrm{~ms}$ before stimulation) are indicated by a long, thin black line and two dotted lines, respectively. $C-\boldsymbol{E}$, Summary of 5 -HT effects on the spontaneous firing obtained from $50 \mathrm{~s}$ of response in this and the following figures is the number of spikes in the excitation and inhibition phases (e.g., the areas marked by red and blue bars in a PSTH; $\boldsymbol{A}-\boldsymbol{a}$ ). For this and subsequent figures, the changes in the mean values with SD and significance levels evaluated by paired $t$ test are indicated at the top of each graph.

\section{Results}

\section{The recorded neurons}

The GPe neurons included in the present study fired at high frequency and with pause characteristics typical of the most numerous population of neurons in the GPe, and the GPi neurons were of a single type of neuron that continuously fire without long pauses (DeLong, 1971). The data on the effects of local application of 5-HT and CGS12066A were obtained from two monkeys. The results of the neurons from the two monkeys were pooled because the spontaneous firing rates and amplitudes of inhibitory and excitatory responses to cortical stimulation ob- 

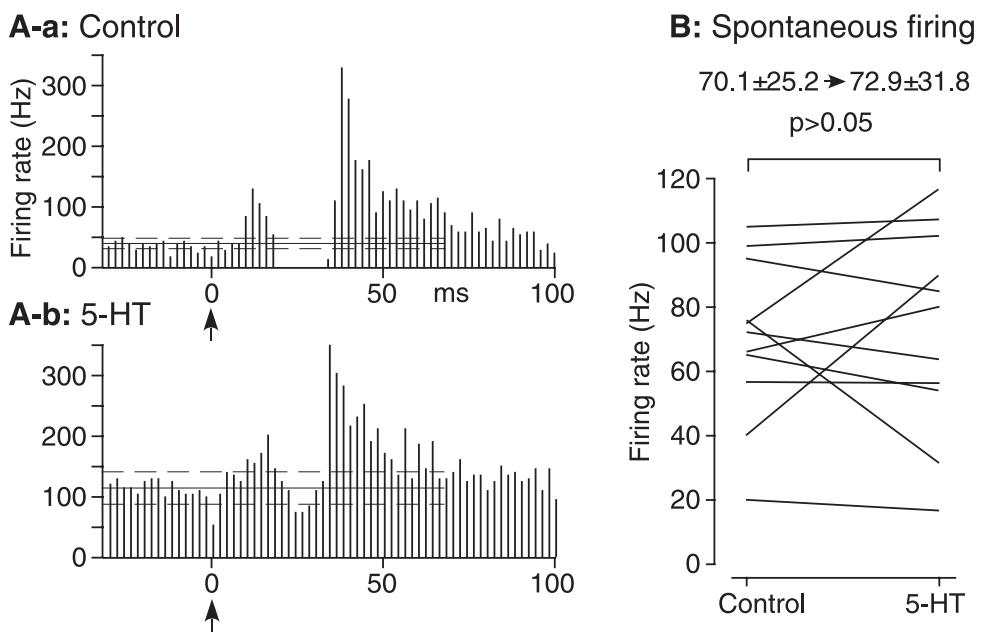

\section{C: Early excitation \\ $762 \pm 767 \rightarrow 389 \pm 458$ \\ $61.1 \%, p<0.02$}

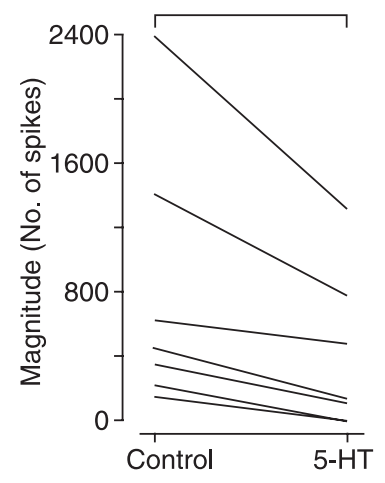

D: Inhibition

$912 \pm 943 \rightarrow 744 \pm 843$ $34.9 \%, p<0.05$

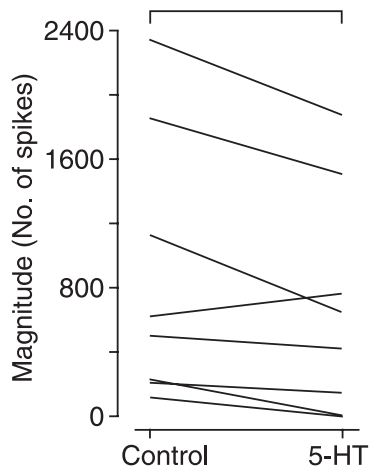

Figure 2. Effects of local application of 5-HT on GPi neurons. $A$, An example of GPi neurons. PSTHs show that 5 -HT $(1 \mathrm{~mm}, 0.2 \mu l)$ increased the firing rate and decreased the early excitatory and inhibitory responses to SMA stimulation. $\boldsymbol{B}-\boldsymbol{D}$, Summary of $5-\mathrm{HT}$ effects on the spontaneous firing obtained from $50 \mathrm{~s}$ of continuous recording $(\boldsymbol{B})$, the magnitude of early excitations $(\boldsymbol{C})$, and the magnitude of inhibitions (D).

tained from these monkeys were the same (ANOVA). The data on the effects of Way100635 and DOI were obtained from another monkey. These neurons responded to stimulation of the hand areas of M1 or SMA and thus were considered to be in the motor territories of the GPe and GPi. The neurons that responded to stimulation of M1 and SMA were pooled because their spontaneous firing rate and the neuronal circuits involved in the generation of the excitatory and inhibitory responses to cortical stimulation were the same (Nambu et al., 2000; Kita et al., 2005b).

\section{Effects of local 5-HT}

Local application of 5-HT exerted variable effects on the spontaneous firing rates of GPe and GPi neurons. In GPe, 5-HT decreased the firing rates of six neurons by $>10 \%$ of baseline and increased firing rates of seven neurons by $>10 \%$; two neurons exhibited less than a $10 \%$ change (Fig. $1 C)$. The six neurons that decreased their firing rate in response to 5-HT had significantly higher baseline rates than the seven neurons that increased their firing rate $(p<0.05$, ANOVA with a post hoc Bonferroni/Dunn test). In GPi, the firing rates of six neurons decreased by $>10 \%$, only two neurons increased by $>10 \%$, and three neurons changed by $<10 \%$ (Fig. 2 ). When all recorded neurons were considered as a group, 5 -HT did not change the mean firing rate of GPe or GPi neurons (Figs. 1C, 2 B). However, 5-HT made interspike intervals more regular and significantly reduced the burst indices for GPe from $0.17 \pm 0.12$ to $0.06 \pm 0.09(n=15$; $p<0.02$, paired $t$ test) and for GPi from $0.13 \pm 0.11$ to $0.05 \pm$ 0.09 ( $n=11 ; p<0.05)$. In both GPe and GPi neurons, 5-HT significantly reduced early excitation and inhibition in response to cortical stimulation (Figs. 1, 2). The 5-HT effect was very of inhibition (E).
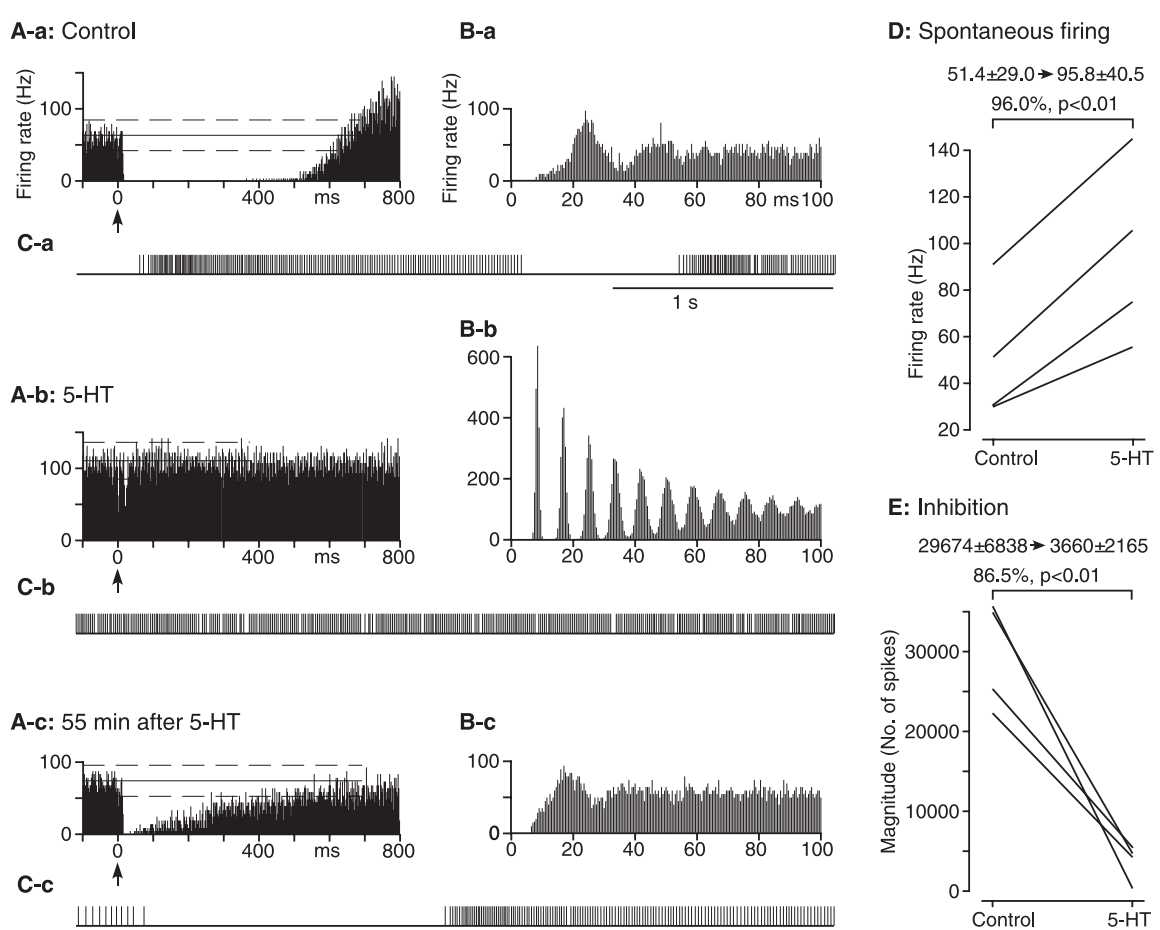

Figure 3. Effects of local application of 5-HT on GPe neurons recorded after muscimol $(0.5 \mu \mathrm{g} / \mu \mathrm{l}$ saline, $0.5-1.0 \mu \mathrm{l})$ injection into STN. $A$, PSTHs of a GPe neuron show that 5 -HT $(1 \mathrm{mM}, 0.2 \mu \mathrm{l})$ reversibly increased the firing rate and greatly decreased the inhibitory response to SMA stimulation. $\boldsymbol{B}, \boldsymbol{C}$, Autocorrelograms and digitized spike traces of the same neuron. $\boldsymbol{D}, \boldsymbol{E}$, Summary of 5 -HT effects on the spontaneous firing rate obtained from $50 \mathrm{~s}$ of continuous recording $(\boldsymbol{D})$ and the magnitude

strong; the inhibitions of half of the tested neurons were totally abolished (Fig. 1 E). The effects of 5-HT were reversible, although the reversal took more than $1 \mathrm{~h}$ (Fig. $1 A, B$ ).

To examine the 5-HT effect on inhibition further, the blockade of the cortico-STN-pallidal pathway by intra-STN injection of muscimol was performed. After the STN blockade, GPe neurons showed long pauses in firing and also responded with longduration inhibitions to stimulation of the motor cortex, as was seen in previous studies (Nambu et al., 2000; Kita et al., 2004). 
A-a: Control

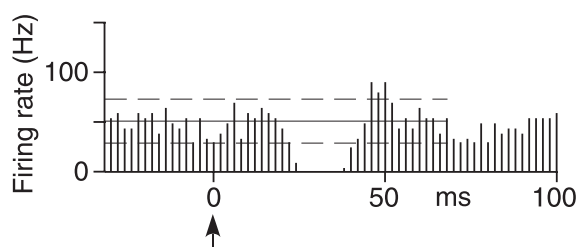

A-b: $5-\mathrm{HT}$

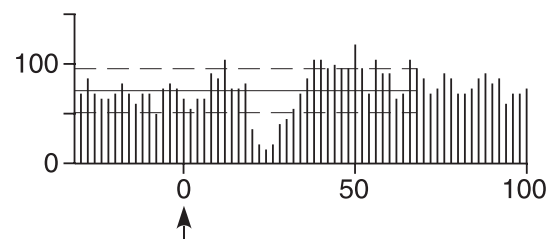

B-a: Control

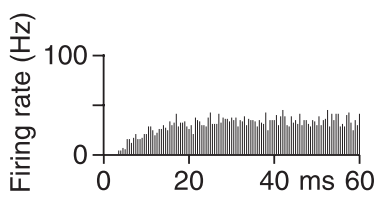

B-b: 5-HT

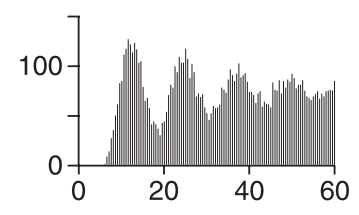

C: Spontaneous firing

$52.7 \pm 18.3 \rightarrow 83.9 \pm 26.6$

$\mathrm{p}<0.005$

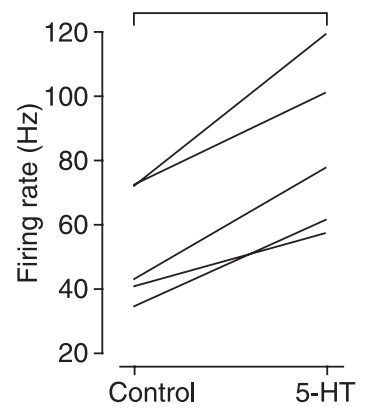

D: Inhibition

$1872 \pm 722 \rightarrow 1024 \pm 352$

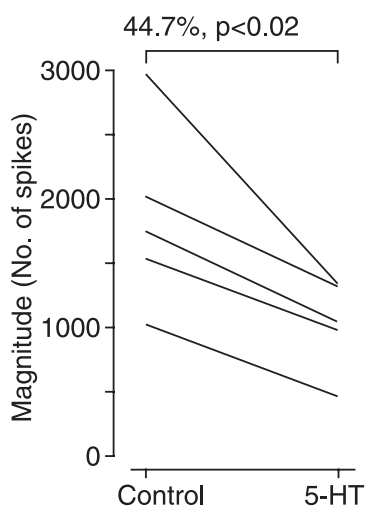

Figure 4. Effects of local application of 5-HT on GPi neurons recorded after muscimol $(0.5 \mu \mathrm{g} / \mu \mathrm{l}$ saline, $0.5-1.0 \mu \mathrm{l})$ injection into STN. A, PSTHs of a GPi neuron show that 5-HT (1 mM, $0.2 \mu \mathrm{l})$ increased the firing rate and decreased the inhibitory response to $\mathrm{M} 1$ stimulation. $\boldsymbol{B}$, Autocorrelograms of the same neuron. $\boldsymbol{C}, \boldsymbol{D}$, Summary of 5 -HT effects on the spontaneous firing rate obtained from 50 s of continuous recording $(C)$ and the magnitude of inhibition $(\boldsymbol{D})$.

Local application of 5-HT greatly decreased the pauses, increased the firing rates (Fig. 3D), made firing intervals very regular (see the multiple peaks in the autocorrelogram in Fig. $3 B-b$ ), and greatly decreased the burst indices from $0.22 \pm 0.12$ to $0.0 \pm 0.0$ $(n=4) .5-\mathrm{HT}$ also greatly decreased the long-lasting inhibition in GPe neurons, and the effect was reversible (Fig. 3A-C,E). The STN blockade made interspike intervals of GPi neurons more regular than under the control condition, and stimulation of the motor cortex induced a short-duration inhibition followed by a rebound-like excitation, as was seen in a previous study (Nambu et al., 2000). Local 5-HT application had similar effects in GPi as in GPe: 5-HT increased firing rates (Fig. $4 A-C$ ) and made interspike intervals more regular (Fig. $4 B-b$ ). The burst indices were not compared because they were already very small before $5-\mathrm{HT}$ application. 5-HT decreased the inhibitory response of all five neurons tested (Fig. $4 A, D$ ).

\section{Effects of local Way100635}

To test whether GPe and GPi neurons receive continuous background inhibition mediated through $5-\mathrm{HT}_{1 \mathrm{~A}}$ receptors, local applications of the selective $5-\mathrm{HT}_{1 \mathrm{~A}}$ receptor antagonist Way100635 were performed. Way100635 slightly but significantly increased the firing rate of both GPe and GPi neurons (Fig. 5 ). The mean burst indices of these neurons were not changed. The mean magnitudes of early excitation and inhibition of these neurons were changed by $<10 \%$ and were not statistically significant.

These results are consistent with the assumption that the activation of postsynaptic $5-\mathrm{HT}_{1 \mathrm{~A}}$ receptors inhibits both GPe and GPi neurons. To examine the possible involvement of other receptors in the inhibition, some of the neurons tested with Way100635 (Way-treated neurons) were subsequently tested with 5-HT. The applications of 5-HT were initiated after assessments of the effects of Way100635 $(\sim 15$ min after the termination of the Way100635 application). As described above, most of the GPe and GPi neurons increased their firing rates slightly after Way100635 application. In both GPe and GPi, 5-HT further increased the mean firing rates (Fig. $5 A, E, G$ ). In addition, 5-HT made the interspike intervals more regular, as can be seen in the autocorrelograms (Fig. $5 B-c, D-c$ ), and greatly decreased burst indices in GPe from $0.14 \pm 0.06$ to $0.04 \pm 0.03(n=6 ; p<0.02$, paired $t$ test $)$ and in GPi from $0.09 \pm 0.03$ to $0.01 \pm 0.02(n=6$; $p<0.01)$. 5-HT did not change the magnitude of early excitation. However, 5-HT significantly decreased the magnitude of inhibition in both nuclei (Fig. $5 F, H$ ).

To examine this further, we tested the effects of 5-CT (a highaffinity agonist for $5-\mathrm{HT}_{1 \mathrm{~A}}, 5-\mathrm{HT}_{1 \mathrm{~B}}, 5-\mathrm{HT}_{1 \mathrm{D}}, 5-\mathrm{HT}_{5}$, and $5-\mathrm{HT}_{7}$ receptors) on Way-pretreated neurons. The 5-CT effects were very similar to those of 5-HT; 5-CT increased the mean firing rates of both GPe and GPi neurons (Fig. 5C,E, G) and at the same time also greatly decreased the burst indices in GPe from $0.12 \pm$ 0.07 to $0.01 \pm 0.02(n=6 ; p<0.02$, paired $t$ test $)$ and in GPi from $0.10 \pm 0.06$ to $0.01 \pm 0.01(n=7 ; p<0.005) .5$-CT failed to alter the magnitude of the early excitation but decreased the magnitude of inhibition in both GPe and GPi neurons (Fig. 5F, H).

\section{Effects of local DOI}

To test the possibility that $5-\mathrm{HT}_{2}$ receptors postsynaptically excite pallidal neurons, the potent $5-\mathrm{HT}_{2}$ agonist DOI was applied to five GPe and five GPi neurons. DOI had no effects on spontaneous firing rates, and cortical stimulation induced responses of these GPe and GPi neurons (in all measurements, the mean changes were $<10 \%$ and paired $t$ tests showed $p>0.05$ ).

\section{Effects of local CGS12066A}

$5-\mathrm{HT}_{1 \mathrm{~B}}$ receptors are the most commonly suggested presynaptic receptors that mediate suppression of GABA release in rat GPe and other areas of the brain (Pickard et al., 1999; Chadha et al., 2000; Matsuoka et al., 2004). This, together with the present results that $5-\mathrm{CT}$ (which is not only a $5-\mathrm{HT}_{1 \mathrm{~A}}$ but also $5-\mathrm{HT}_{1 \mathrm{~B}}$ agonist) suppressed the inhibition, suggested the possibility that $5-\mathrm{HT}_{1 \mathrm{~B}}$ receptors mediate the suppression of the inhibition in GPe and GPi. We tested this possibility through application of the 5- $\mathrm{HT}_{1 \mathrm{~B}}$ receptor agonist CGS12066A.

CGS12066A increased the mean firing rate of both GPe and GPi neurons (Fig. 6A,D) but did not significantly decrease the burst indices in GPe from $0.13 \pm 0.12$ to $0.07 \pm 0.09(n=7 ; p>$ 0.05 , paired $t$ test) and in GPi from $0.09 \pm 0.12$ to $0.05 \pm 0.05$ $(n=6 ; p>0.05)$. CGS12066A decreased the early excitation of both GPe and GPi neurons (Fig. 6B,E). CGS12066A also significantly decreased the magnitude of inhibition in both GPe and GPi (Fig. 6C,F). The degree of the decrease of inhibition in GPe neurons by CGS12066A was moderate and was significantly less than when using 5-HT alone (compare Figs. $1 E, 6 C)(p<0.05$, 


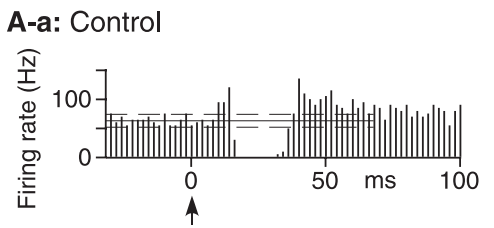

A-b: Way 100635

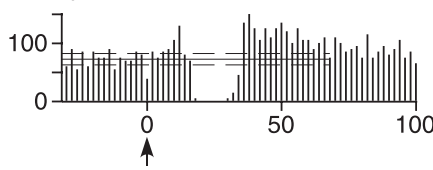

A-c: Way100635 + 5-HT

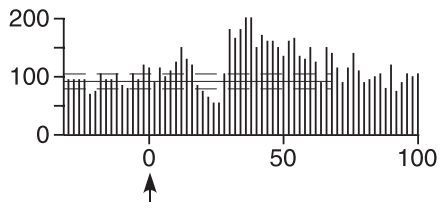

C-a: Control

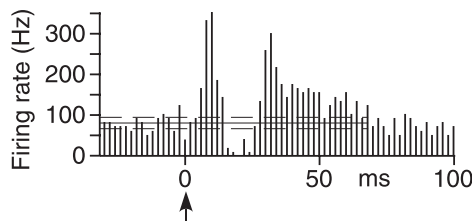

C-b: Way100635

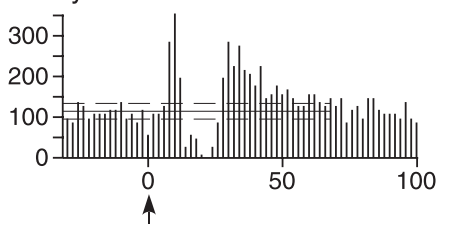

C-c: Way100635 + 5-CT

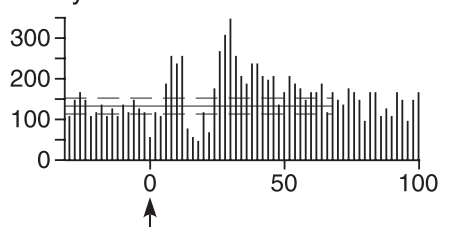

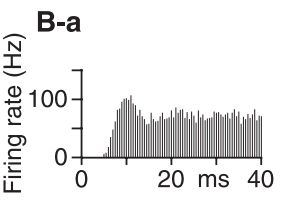
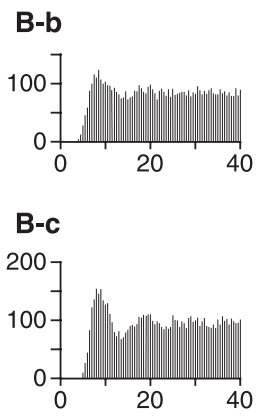

D-a

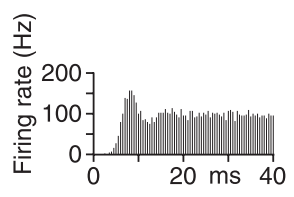

D-b
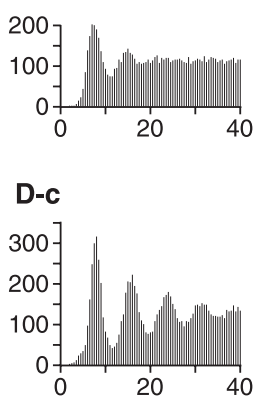

E: Firing rate of $\mathrm{GPe}$

5 -HT: $79.7 \pm 22.2 \rightarrow 96.3 \pm 24.2$

$21.4 \%, p<0.05$

5-CT: $107.7 \pm 19.6 \rightarrow 125.0 \pm 10.6$

$18.2 \%, p<0.05$
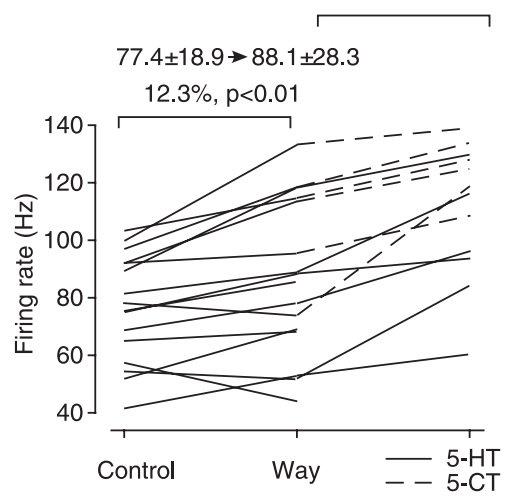

F: Inhibition of GPe

$5-\mathrm{HT}: 693 \pm 336 \rightarrow 358 \pm 351$ $59.1 \%, p<0.001$

5 CT: $790 \pm 562 \rightarrow 374 \pm 314$ $59.4 \%, p<0.05$

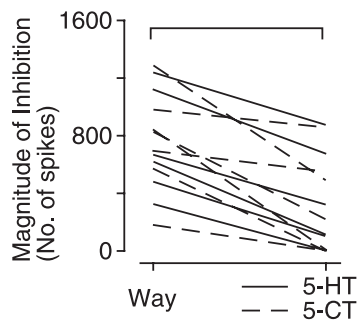

G: Firing rate of GPi

$5-\mathrm{HT}: 91.7 \pm 35.5 \rightarrow 109.2 \pm 42.5$

$17.3 \%, p<0.05$

5-CT: $89.7 \pm 20.9 \rightarrow 106.3 \pm 28.4$ $17.7 \%, p<0.05$

$\longrightarrow$

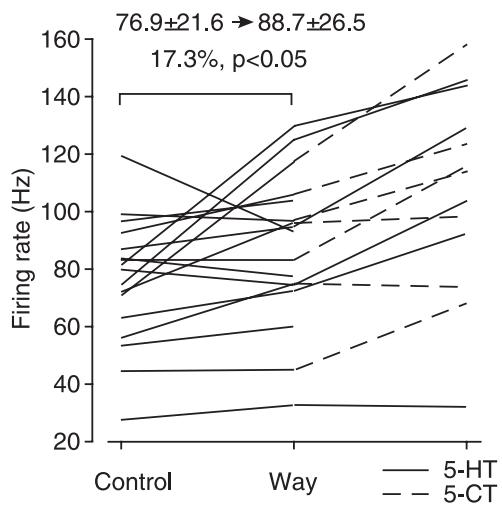

H: Inhibition of GPi

5 -HT: $894 \pm 467 \rightarrow 638 \pm 409$ $33.8 \%, p<0.001$

5 -CT: $758 \pm 328 \rightarrow 374 \pm 314$ $60.5 \%, p<0.02$

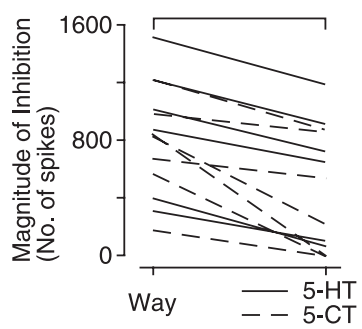

Figure 5. Effect of local application of Way 100635 and subsequent application of 5-HT and 5-CT on GPe and GPi neurons. $A, B$, An example of GPi neurons. PSTHs and autocorrelograms show that Way $100635(1 \mathrm{~mm}, 0.1 \mu \mathrm{l})$ increased the firing rate without changing the early excitatory and inhibitory responses to SMA stimulation. $A-\boldsymbol{c}, \boldsymbol{B}$-c, Subsequent application of 5 -HT (1 mM, $0.2 \mu l)$ further increased the firing rate, increased the regularity of firing (development of prominent peaks in the autocorrelogram), and decreased the inhibitory response to SMA stimulation. $C, D$, An example of GPe neurons. PSTHs and autocorrelograms show that Way $100635(1 \mathrm{~mm}, 0.1 \mu \mathrm{l})$ increased the firing rate without changing the early excitatory and inhibitory responses to M1 stimulation. C-c, D-C, Subsequent application of $5-\mathrm{CT}(1 \mathrm{~mm}, 0.03 \mu \mathrm{l})$ further increased the firing rate, greatly increased the regularity of firing, and decreased the inhibitory response to $\mathrm{M} 1$ stimulation. $\boldsymbol{E}-\boldsymbol{H}$, Summary of the effects of local application of Way 100635 and subsequent application of 5 -HT and 5 -CT on spontaneous firing obtained from 50 s of continuous recording $(\boldsymbol{E}, \boldsymbol{G})$ and the magnitude of inhibition $(\boldsymbol{F}, \boldsymbol{H})$ of GPe and GPi neurons.

ANOVA with a post hoc Bonferroni/Dunn test) or 5-HT or 5-CT on Way-treated neurons (compare Figs. 5F, 6C) (5-HT, $p<0.01$; 5 -CT, $p<0.005$; ANOVA with a post hoc Bonferroni/Dunn test). The decrease of inhibition in GPi neurons using CGS12066A was comparable to that using 5-HT and 5-CT.

\section{Discussion}

We expected that the effects of 5-HT would be complex because of the existence of various receptor subtypes on presynaptic and postsynaptic membranes in the pallidum. After reviewing the literature, we decided to test three possibilities with physiological studies in awake monkeys. The actions of 5-HT can be examined in monkeys because the spontaneous firing and excitatory and inhibitory responses of pallidal neurons to M1 and SMA stimu- lation have been characterized in previous studies (Nambu et al., 2000; Kita et al., 2004, 2005b).

The first possibility was that 5-HT suppresses GABAergic inhibitory responses to cortical stimulation through presynaptic $5-\mathrm{HT}_{1 \mathrm{~B}}$ receptors, which are densely expressed on axons and axon terminals in the pallidum (Bonaventure et al., 1998; Castro et al., 1998; Riad et al., 2000; Sari, 2004; Mostany et al., 2005). A $5-\mathrm{HT}_{1 \mathrm{~B}}$ receptor agonist inhibited ${ }^{3} \mathrm{H}-\mathrm{GABA}$ release from rat GPe slices (Chadha et al., 2000), and activation of presynaptic $5-\mathrm{HT}_{1 \mathrm{~B}}$ receptors suppresses GABAergic inhibition in other brain areas (Pickard et al., 1999; Matsuoka et al., 2004).

The second possibility was that 5-HT decreases the firing of pallidal neurons through postsynaptic $5-\mathrm{HT}_{1 \mathrm{~A}}$ receptors. The 


\section{Effects of CGS12066A on GPe neurons}

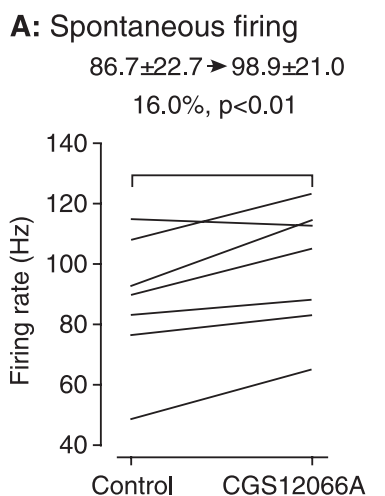

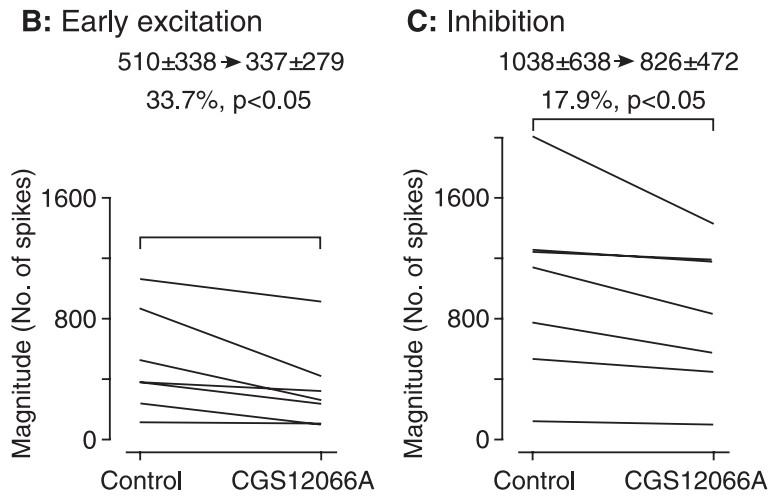

Effects of CGS12066A on GPi neurons

\section{D: Spontaneous firing}

$81.5 \pm 41.3 \rightarrow 97.3 \pm 40.2$

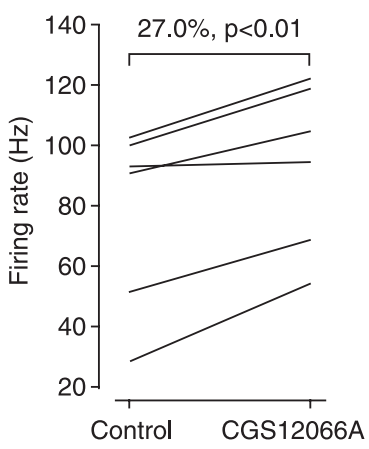

\section{E: Early excitation}

$777 \pm 422 \rightarrow 644 \pm 348$

$16.6 \%, p<0.05$

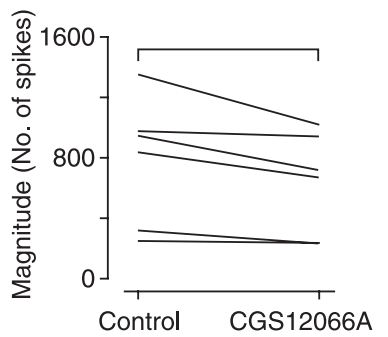

F: Inhibition

$994 \pm 457 \rightarrow 776 \pm 464$ $33.7 \%, p<0.02$

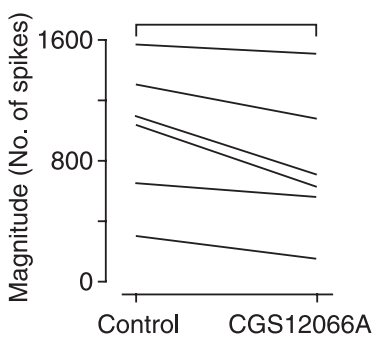

Figure 6. Summary of local application of CGS12066A on the spontaneous firing rate obtained from $50 \mathrm{~s}$ of continuous recording $(\boldsymbol{A}, \boldsymbol{D})$, the magnitude of early excitation $(\boldsymbol{B}, \boldsymbol{E})$, and the magnitude of inhibition $(\boldsymbol{C}, \boldsymbol{F})$ of GPe $(\boldsymbol{A}-\boldsymbol{C})$ and GPi $(\boldsymbol{D}-\boldsymbol{F})$ neurons.

Table 1. Summary of effects of local application of 5-HT agonists and antagonists on GPe and GPi neurons

\begin{tabular}{|c|c|c|c|c|}
\hline & Firing rate & Burst index & Early excitation & Inhibition \\
\hline \multirow[t]{2}{*}{$5-\mathrm{HT}$} & Variable & GPe:64.7\% & GPe: 17.9\% & GPe: $58.8 \%$ \\
\hline & & $\downarrow$ GPi:61.5\% & $\downarrow$ GPi: 61.1\% & $\downarrow$ GPi: $34.9 \%$ \\
\hline \multirow[t]{2}{*}{ Way100635 } & $\uparrow$ GPe: $12.3 \%$ & Unchanged & Unchanged & Unchanged \\
\hline & GPi: 17.3\% & & & \\
\hline \multirow[t]{2}{*}{ Way100635 + 5-HT } & $\uparrow$ GPe: $21.4 \%$ & GPe: 71.4\% & Unchanged & GPe: $59.1 \%$ \\
\hline & GPi:17.3\% & $\downarrow$ GPi: 88.9\% & & $\downarrow$ GPi: $33.8 \%$ \\
\hline \multirow[t]{2}{*}{ Way100635 + 5-CT } & $\uparrow$ GPe: $18.2 \%$ & GPe: $91.7 \%$ & Unchanged & GPe: $59.4 \%$ \\
\hline & GPi: 17.7\% & $\downarrow$ GPi: $90.0 \%$ & & $\downarrow$ GPi: $60.5 \%$ \\
\hline DOI & Unchanged & Unchanged & Unchanged & Unchanged \\
\hline \multirow[t]{2}{*}{ CGS12066A } & $\uparrow$ GPe: $16.0 \%$ & Unchanged & GPe: $33.7 \%$ & GPe: $17.9 \%$ \\
\hline & GPi: $27.0 \%$ & & $\downarrow$ GPi: $16.6 \%$ & $\downarrow$ GPi: $33.7 \%$ \\
\hline
\end{tabular}

$\uparrow$, Increased; $\downarrow$, decreased; Way100635, 5- $\mathrm{HT}_{1 \mathrm{~A}}$ antagonist; $5-\mathrm{CT}, 5-\mathrm{HT}_{1 \mathrm{~A}}, 5-\mathrm{HT}_{1 \mathrm{~B}}, 5-\mathrm{HT}_{1 \mathrm{D}}, 5-\mathrm{HT}_{5}$, and $5-\mathrm{HT}_{7}$ agonist; $\mathrm{DOI}, 5-\mathrm{HT}_{1 \mathrm{~B}}$ agonist.

tivation of $5-\mathrm{HT}_{2 \mathrm{C}}$ receptors postsynaptically excites $\mathrm{SNr}$ neurons (Rick et al., 1995), and activation of $5-\mathrm{HT}_{4}$ or $5-\mathrm{HT}_{7}$ receptors, but not $5-\mathrm{HT}_{2 \mathrm{C}}$ receptors, excites noncholinergic ventral pallidal neurons (Bengtson et al., 2004). Because of the resemblance of physiological properties and afferent inputs of the ventral pallidal and $\mathrm{SNr}$ neurons to GPe and GPi neurons, these studies suggested the possibility that $5-\mathrm{HT}$ may excite GPe and GPi neurons through different receptors.

The results of the present study, summarized in Table 1, suggest that 5-HT exerts strong modulation on inhibitory and excitatory responses to cortical stimulation in the GPe and GPi. In advanced stages of Parkinson's disease, the number of 5-HT neurons and 5-HT uptake sites in the basal ganglia (including the pallidum) decrease (Halliday et al., 1990; Jellinger, 1990; Chinaglia et al., 1993; Kish, 2003). A decrease in pallidal 5-HT transmission may decrease the modulatory effects on inhibitory and excitatory synaptic transmission and contribute to pathological changes such as a significant increase in burst firing in the pallidum. Synaptic inputs modulate autonomous activity of GPe and GPi neurons and generate burst firing (Kita et al., 2004, 2005b; Galvan et al., 2005). The clinical finding of the beneficial $5-\mathrm{HT}_{1}$ agonist treatments for parkinsonism could be attributable to the suppression of the burst firing in the pallidum (Johnston and Brotchie, 2004). The present results also suggest that the beneficial effects of the $5-\mathrm{HT}_{4}$ agonist and $5-\mathrm{HT}_{2}$ antagonist treatments may be because of their effects outside of the pallidum (Henderson et al., 1992; Asai et al., 2005).

\section{Decrease of inhibition}

The effects of 5-HT agonists and antagonists used in this study were very similar in the GPe and GPi. Thus, the following discussion applies to neurons in both nuclei. The inhibitory response of pallidal neurons to cortical stimulation was $\mathrm{GABA}_{\mathrm{A}}$-receptor mediated and induced by the cortico-striato-pallidal and pallido-pallidal, including local collateral, pathways (Nambu et al., 2000; Kita et al., 2004, 2005b). Application of 5-HT alone, 5-HT or 5-CT on Way-treated neurons, and CGS12066A all decreased the magnitude of the inhibitory responses. The effect of 5-HT alone or 5-HT or 5-CT on Way-treated neurons was very strong in GPe neurons. However, the effect of CGS12066A in the GPe was

pallidal neurons express $5-\mathrm{HT}_{1 \mathrm{~A}}$ receptors, which mediate postsynaptic inhibition in other brain areas (Stevens et al., 1992; Stanford et al., 2005).

The third possibility was that activation of postsynaptic $5-\mathrm{HT}_{2 \mathrm{C}}, 5-\mathrm{HT}_{4}$, or 5- $\mathrm{HT}_{7}$ receptors excites pallidal neurons. Ac- moderate. These observations suggest involvement of additional presynaptic receptors or other mechanisms in the 5-HT suppression of inhibition in GPe. The effects of these agonists on the inhibition of GPi neurons were similar and moderate. The suppression of inhibition by 5 -HT was consistent with our initial assumption that was 
made from literature reviews. This result may also explain the finding of a recent study that local application of $5-\mathrm{HT}$ or the $5-\mathrm{HT}_{1 \mathrm{~B}}$ receptor agonist $\mathrm{N}$-[4-[[5-[3-(2-aminoethyl)-1 H-indol-5-yl]1,2,4-oxadiazol-3-yl]methyl]phenyl]-methanesulfonamide excites most of the GPe neurons in anesthetized rats (Querejeta et al., 2005).

We believe that 5-HT decreased GABA release not only from striatal terminals but also from GPe axon terminals because of the following reasons: (1) the increase in spontaneous firing by 5 -HT suggests a decrease in background inhibition; (2) the background inhibition in both segments of the pallidum was believed to be attributable to tonic inhibition exerted by spontaneously active GPe neurons (Kita et al., 2004); and (3) the powerful 5-HT or 5 -CT effects on Way-treated neurons (making interspike intervals more regular) resembled the effect of local gabazine (a $\mathrm{GABA}_{\mathrm{A}}$ blocker) application, which was attributed to the blockade of the inhibition of GPe axons (Kita et al., 2004).

\section{Decrease of excitation}

Stimulation of the motor cortex activates the cortico-STN-pallidal pathway and evokes glutamatergic early excitation in pallidal neurons (Nambu et al., 2000; Kita et al., 2004, 2005b). Application of 5-HT and the 5- $\mathrm{HT}_{1 \mathrm{~B}}$ agonist CGS12066A decreased the early excitation. The CGS12066A effects may not be mediated by 5- $\mathrm{HT}_{1 \mathrm{~B}}$ receptors because of the following reasons: (1) 5-HT or 5-CT failed to decrease excitation of Way-treated neurons, and (2) it is possible that CGS12066A activated 5- $\mathrm{HT}_{1 \mathrm{~A}}$ receptors and modulated AMPA receptors (Cai et al., 2002), although CGS12066A is a less potent $5-\mathrm{HT}_{1 \mathrm{~A}}$ receptor agonist.

It is interesting to note that the large decrease in the spontaneous firing rate and the decrease of early excitation of some GPe neurons by 5 -HT were no longer observed when Way-treated neurons were tested with $5-\mathrm{HT}$. This result also suggested that 5-HT effectively decreased glutamatergic excitation through $5-\mathrm{HT}_{1 \mathrm{~A}}$ receptors and thus decreased the firing rate, which is similar to the effect of local ionotropic glutamate antagonist application (Kita et al., 2004). These results suggested that 5-HT decreased both excitatory and inhibitory inputs in GPe and GPi and that the highly variable effect of 5-HT on the firing rate (particularly on GPe neurons) was caused by an overlapping occurrence of two functionally antagonizing presynaptic effects.

The expression of $5-\mathrm{HT}_{1 \mathrm{~A}}$ receptors in the pallidum is reported to be low (Pompeiano et al., 1994; Kia et al., 1996). However, the binding sites are increased during memory formation, suggesting the existence of control mechanisms for receptor expression in the GPe (Luna-Munguia et al., 2005). Administration of 5- $\mathrm{HT}_{1 \mathrm{~A}}$ agonists improved movement disorders of Parkinson's disease (Nicholson and Brotchie, 2002; Johnston and Brotchie, 2004). The present results suggest that $5-\mathrm{HT}_{1 \mathrm{~A}}$ agonists would decrease glutamatergic excitation in both GPe and GPi.

\section{Postsynaptic inhibition and excitation}

The existence of postsynaptic inhibitory effects of 5-HT was uncertain. Application of Way100635 slightly but significantly increased the spontaneous firing rate of neurons without altering the magnitude of excitatory or inhibitory responses to cortical stimulation in both GPe and GPi. Although increases in the firing rate were significant and suggested that 5-HT exerted background inhibition through $5-\mathrm{HT}_{1 \mathrm{~A}}$ receptors, explanation of the data requires caution. Because of the way the magnitude of the excitation was defined, an increase in the excitation could be underevaluated when the spontaneous firing rate of the neurons increased. For instance, when a neuron fires at near maximum rate of capacity, an excitatory input would not exert a strong response. Conversely, an increase in the spontaneous firing rate with a same magnitude of excitatory response could imply an increase in the excitatory input. Thus, the increased firing rates observed using Way100635 could be primarily caused by increases in excitation, which can be expected if 5-HT continuously suppressed the inputs as discussed above.

The existence of postsynaptic excitatory effects of 5-HT was also uncertain. Applications of the potent $5-\mathrm{HT}_{2}$ agonist DOI were ineffective with both GPe and GPi neurons. The failure of DOI to excite GPi neurons was surprising because 5-HT has been shown to postsynaptically excite rat $\mathrm{SNr}$ neurons in vitro through $5-\mathrm{HT}_{2 \mathrm{C}}$ receptors (Rick et al., 1995). The GPi and $\mathrm{SNr}$ are basal ganglia output nuclei, and their physiological properties and afferent inputs resemble each other. It is possible that rat $\mathrm{SNr}$ and monkey GPi may express $5-\mathrm{HT}_{2 \mathrm{c}}$ receptors to different degrees.

\section{Conclusion}

The present study using awake monkeys provided evidence that 5 -HT is involved in the control of neuronal activity of both segments of the pallidum by modulating GABAergic inhibition and glutamatergic excitation. Although in vivo experiments could not determine the receptor types or active sites of the observed effects, the present results suggest the following possibilities: (1) 5-HT suppresses GABAergic inhibition through presynaptic $5-\mathrm{HT}_{1 \mathrm{~B}}$ receptors; (2) in the GPe, the suppression may involve additional receptors or mechanisms; and (3) 5-HT suppresses ionotropic glutamatergic excitation probably through $5-\mathrm{HT}_{1 \mathrm{~A}}$ (but not $\left.5-\mathrm{HT}_{1 \mathrm{~B}}\right)$ receptors located at presynaptic and/or postsynaptic sites. The present study did not isolate or identify the existence of strong postsynaptic inhibitory or excitatory effects of 5-HT. However, the observations suggest that the postsynaptic effects do not involve 5- $\mathrm{HT}_{2}$ receptors. Thus, it is likely that 5-HT modulates synaptic inputs of both segments of the pallidum and exerts significant roles in movement control.

\section{References}

Appel NM, Mitchell WM, Garlick RK, Glennon RA, Teitler M, De Souza EB (1990) Autoradiographic characterization of ( \pm )-1-(2,5-dimethoxy-4[125I] iodophenyl)-2-amino-propane ([125I]DOI) binding to 5-HT2 and 5-HT1c receptors in rat brain. J Pharmacol Exp Ther 255:843-857.

Asai H, Udaka F, Hirano M, Minami T, Oda M, Kubori T, Nishinaka K, Kameyama M, Ueno S (2005) Increased gastric motility during 5-HT4 agonist therapy reduces response fluctuations in Parkinson's disease. Parkinsonism Relat Disord 11:499-502.

Bengtson CP, Lee DJ, Osborne PB (2004) Opposing electrophysiological actions of 5-HT on noncholinergic and cholinergic neurons in the rat ventral pallidum in vitro. J Neurophysiol 92:433-443.

Bonaventure P, Voorn P, Luyten WH, Jurzak M, Schotte A, Leysen JE (1998) Detailed mapping of serotonin 5-HT1B and 5-HT1D receptor messenger RNA and ligand binding sites in guinea-pig brain and trigeminal ganglion: clues for function. Neuroscience 82:469-484.

Boraud T, Bezard E, Bioulac B, Gross CE (2001) Dopamine agonist-induced dyskinesias are correlated to both firing pattern and frequency alterations of pallidal neurones in the MPTP-treated monkey. Brain 124:546-557.

Cai X, Gu Z, Zhong P, Ren Y, Yan Z (2002) Serotonin 5-HT1A receptors regulate AMPA receptor channels through inhibiting $\mathrm{Ca} 2+/$ calmodulindependent kinase II in prefrontal cortical pyramidal neurons. J Biol Chem 277:36553-36562.

Castro ME, Pascual J, Romon T, Berciano J, Figols J, Pazos A (1998) 5-HT1B receptor binding in degenerative movement disorders. Brain Res 790:323-328.

Chadha A, Sur C, Atack J, Duty S (2000) The 5HT(1B) receptor agonist, CP-93129, inhibits $[(3) \mathrm{H}]$-GABA release from rat globus pallidus slices and reverses akinesia following intrapallidal injection in the reserpinetreated rat. Br J Pharmacol 130:1927-1932.

Charara A, Parent A (1994) Brainstem dopaminergic, cholinergic and sero- 
toninergic afferents to the pallidum in the squirrel monkey. Brain Res 640:155-170.

Chinaglia G, Landwehrmeyer B, Probst A, Palacios JM (1993) Serotoninergic terminal transporters are differentially affected in Parkinson's disease and progressive supranuclear palsy: an autoradiographic study with [3H] citalopram. Neuroscience 54:691-699.

DeLong MR (1971) Activity of pallidal neurons during movement. J Neurophysiol 34:414-427.

Doder M, Rabiner EA, Turjanski N, Lees AJ, Brooks DJ (2003) Tremor in Parkinson's disease and serotonergic dysfunction: an 11C-WAY 100635 PET study. Neurology 60:601-605.

Filion M, Tremblay L (1991) Abnormal spontaneous activity of globus pallidus neurons in monkeys with MPTP-induced parkinsonism. Brain Res 547:142-151.

Galvan A, Villalba RM, West SM, Maidment NT, Ackerson LC, Smith Y, Wichmann T (2005) GABAergic modulation of the activity of globus pallidus neurons in primates: in vivo analysis of the functions of GABA receptors and GABA transporters. J Neurophysiol 94:990-1000.

Halliday GM, Blumbergs PC, Cotton RG, Blessing WW, Geffen LB (1990) Loss of brainstem serotonin- and substance P-containing neurons in Parkinson's disease. Brain Res 510:104-107.

Henderson J, Yiannikas C, Graham JS (1992) Effect of ritanserin, a highly selective 5-HT2 receptor antagonist, on Parkinson's disease. Clin Exp Neurol 29:277-282.

Jackson MJ, Al-Barghouthy G, Pearce RK, Smith L, Hagan JJ, Jenner P (2004) Effect of 5-HT1B/D receptor agonist and antagonist administration on motor function in haloperidol and MPTP-treated common marmosets. Pharmacol Biochem Behav 79:391-400.

Jellinger K (1990) New developments in the pathology of Parkinson's disease. Adv Neurol 53:1-16.

Johnston TH, Brotchie JM (2004) Drugs in development for Parkinson's disease. Curr Opin Investig Drugs 5:720-726.

Kia HK, Miquel MC, Brisorgueil MJ, Daval G, Riad M, El Mestikawy S, Hamon M, Verge D (1996) Immunocytochemical localization of serotonin 1 A receptors in the rat central nervous system. J Comp Neurol 365:289-305.

Kish SJ (2003) Biochemistry of Parkinson's disease: is a brain serotonergic deficiency a characteristic of idiopathic Parkinson's disease? Adv Neurol 91:39-49.

Kita H, Nambu A, Kaneda K, Tachibana Y, Takada M (2004) Role of ionotropic glutamatergic and GABAergic inputs on the firing activity of neurons in the external pallidum in awake monkeys. J Neurophysiol 92:3069-3084.

Kita H, Tachibana Y, Nambu A, Chiken S (2005a) Balance of monosynaptic excitatory and disynaptic inhibitory responses of the globus pallidus induced after stimulation of the subthalamic nucleus in the monkey. J Neurosci 25:8611-8619.

Kita H, Tachibana Y, Nambu A (2005b) Glutamatergic and GABAergic control of pallidal activity in monkeys. In: The basal ganglia VIII (Bolam JP, Magill PJ, eds) pp 545-554. New York: Springer.

Kita H, Chiken S, Tachibana Y, Nambu A (2006) Origins of $\mathrm{GABA}_{\mathrm{A}}$ and $\mathrm{GABA}_{\mathrm{B}}$ receptor-mediated responses of globus pallidus induced after stimulation of the putamen in the monkey. J Neurosci 26:6554-6562.

Legendy CR, Salcman M (1985) Bursts and recurrences of bursts in the spike trains of spontaneously active striate cortex neurons. J Neurophysiol 53:926-939.

Luna-Munguia H, Manuel-Apolinar L, Rocha L, Meneses A (2005) 5-HT1A receptor expression during memory formation. Psychopharmacology (Berl) 181:309-318.

Mano N, Yamamoto K (1978) Automatic and reliable discrimination between simple and complex spikes of a cerebellar Purkinje cell. In: Integrative control functions of the brain, Vol I (Ito M, Tsukahara N, Kubota K, Yagi K, eds), pp 212-214. Tokyo: Kodansha.

Matsuoka T, Hasuo H, Akasu T (2004) 5-Hydroxytryptamine 1B receptors mediate presynaptic inhibition of monosynaptic IPSC in the rat dorsolateral septal nucleus. Neurosci Res 48:229-238.

Mostany R, Pazos A, Castro ME (2005) Autoradiographic characterisation of [35S] GTPgammaS binding stimulation mediated by $5-\mathrm{HT} 1 \mathrm{~B}$ receptor in postmortem human brain. Neuropharmacology 48:25-33.

Nambu A (2004) A new dynamic model of the cortico-basal ganglia loop. Prog Brain Res 143:461-466.

Nambu A, Tokuno H, Hamada I, Kita H, Imanishi M, Akazawa T, Ikeuchi Y,
Hasegawa N (2000) Excitatory cortical inputs to pallidal neurons via the subthalamic nucleus in the monkey. J Neurophysiol 84:289-300.

Neumaier JF, Sexton TJ, Yracheta J, Diaz AM, Brownfield M (2001) Localization of 5-HT(7) receptors in rat brain by immunocytochemistry, in situ hybridization, and agonist stimulated cFos expression. J Chem Neuroanat 21:63-73.

Nicholson SL, Brotchie JM (2002) 5-hydroxytryptamine (5-HT, serotonin) and Parkinson's disease - opportunities for novel therapeutics to reduce the problems of levodopa therapy. Eur J Neurol 9 [Suppl 3]:1-6.

Nini A, Feingold A, Slovin H, Bergman H (1995) Neurons in the globus pallidus do not show correlated activity in the normal monkey, but phaselocked oscillations appear in the MPTP model of parkinsonism. J Neurophysiol 74:1800-1805.

Pasik P, Pasik T, Pecci-Saavedra J, Holstein GR, Yahr MD (1984) Serotonin in pallidal neuronal circuits: an immunocytochemical study in monkeys. Adv Neurol 40:63-76.

Perkins MN, Stone TW (1983) Neuronal responses to 5-hydroxytryptamine and dorsal raphe stimulation within the globus pallidus of the rat. Exp Neurol 79:118-129.

Pickard GE, Smith BN, Belenky M, Rea MA, Dudek FE, Sollars PJ (1999) $5-\mathrm{HT}_{1 \mathrm{~B}}$ receptor-mediated presynaptic inhibition of retinal input to the suprachiasmatic nucleus. J Neurosci 19:4034-4045.

Pompeiano M, Palacios JM, Mengod G (1994) Distribution of the serotonin 5-HT2 receptor family mRNAs: comparison between 5-HT2A and 5-HT2C receptors. Brain Res Mol Brain Res 23:163-178.

Querejeta E, Oviedo-Chavez A, Araujo-Alvarez JM, Quinones-Cardenas AR, Delgado A (2005) In vivo effects of local activation and blockade of 5-HT1B receptors on globus pallidus neuronal spiking. Brain Res 1043:186-194.

Riad M, Garcia S, Watkins KC, Jodoin N, Doucet E, Langlois X, el Mestikawy S, Hamon M, Descarries L (2000) Somatodendritic localization of 5-HT1A and preterminal axonal localization of 5-HT1B serotonin receptors in adult rat brain. J Comp Neurol 417:181-194.

Rick CE, Stanford IM, Lacey MG (1995) Excitation of rat substantia nigra pars reticulata neurons by 5 -hydroxytryptamine in vitro: evidence for a direct action mediated by 5 -hydroxytryptamine2C receptors. Neuroscience 69:903-913.

Sari Y (2004) Serotonin1B receptors: from protein to physiological function and behavior. Neurosci Biobehav Rev 28:565-582.

Sari Y, Miquel MC, Brisorgueil MJ, Ruiz G, Doucet E, Hamon M, Verge D (1999) Cellular and subcellular localization of 5-hydroxytryptamine1B receptors in the rat central nervous system: immunocytochemical, autoradiographic and lesion studies. Neuroscience 88:899-915.

Stanford IM, Kantaria MA, Chahal HS, Loucif KC, Wilson CL (2005) 5 -Hydroxytryptamine induced excitation and inhibition in the subthalamic nucleus: action at 5-HT(2C), 5- $\mathrm{HT}(4)$ and $5-\mathrm{HT}(1 \mathrm{~A})$ receptors. Neuropharmacology 49:1228-1234.

Stevens DR, McCarley RW, Greene RW (1992) Serotonin1 and serotonin2 receptors hyperpolarize and depolarize separate populations of medial pontine reticular formation neurons in vitro. Neuroscience 47:545-553.

Ullmer C, Boddeke HG, Schmuck K, Lubbert H (1996) 5-HT2B receptormediated calcium release from ryanodine-sensitive intracellular stores in human pulmonary artery endothelial cells. Br J Pharmacol 117:1081-1088.

Vertes RP (1991) A PHA-L analysis of ascending projections of the dorsal raphe nucleus in the rat. J Comp Neurol 313:643-668.

Vilaro MT, Cortes R, Gerald C, Branchek TA, Palacios JM, Mengod G (1996) Localization of 5-HT4 receptor mRNA in rat brain by in situ hybridization histochemistry. Brain Res Mol Brain Res 43:356-360.

Waeber C, Moskowitz MA (1995) [3H]sumatriptan labels both 5-HT1D and 5-HT1F receptor binding sites in the guinea pig brain: an autoradiographic study. Naunyn Schmiedebergs Arch Pharmacol 352:263-275.

Wichmann T, Soares J (2006) Neuronal firing before and after burst discharges in the monkey basal ganglia is predictably patterned in the normal state and altered in parkinsonism. J Neurophysiol 95:2120-2133.

Wright DE, Seroogy KB, Lundgren KH, Davis BM, Jennes L (1995) Comparative localization of serotonin $1 \mathrm{~A}, 1 \mathrm{C}$, and 2 receptor subtype mRNAs in rat brain. J Comp Neurol 351:357-373.

Yoshida S, Nambu A, Jinnai K (1993) The distribution of the globus pallidus neurons with input from various cortical areas in the monkeys. Brain Res 611:170-174. 